\title{
Current clinical perspectives on myocardial angiogenesis
}

\author{
Debabrata Mukherjee \\ Division of Cardiology, The University of Michigan, Ann Arbor, MI, USA
}

\begin{abstract}
Currently accepted modalities of treatment for atherosclerotic coronary artery disease (CAD) include pharmacological therapy, and revascularization with either bypass surgery or percutaneous coronary intervention (PCI). Similarly, conventional treatment of congestive heart failure (HF) is limited to medical therapy, temporary assist devices and in a select few, cardiac transplantation. A significant subset of patients with severe symptomatic CAD and end stage HF is not eligible for these traditional methods of treatment. In spite of maximal medical and revascularization therapy, these patients may not get adequate symptomatic relief. After a decade of investigations, gene therapy is emerging as a promising therapeutic option for this group of patients. This review discusses myocardial angiogenesis as a therapeutic modality in these patients including therapeutic angiogenesis with growth factors and cell transplantation. (Mol Cell Biochem 264: 157-167, 2004)
\end{abstract}

Key words: angiogenesis, growth factors, cell transplantation, coronary artery disease

\section{Introduction}

There is a growing population of patients with coronary artery disease (CAD) and heart failure (HF) who have refractory symptoms despite maximal medical therapy. A significant proportion of these patients may not be candidates for revascularization with either percutaneous coronary intervention (PCI) or coronary artery bypass surgery (CABG) [1]. These include symptomatic patients with severe diffuse disease in native coronary vessels and not candidates for PCI or CABG; and patients with recurrent narrowing and occlusion of bypass conduits after successful surgery with no further revascularization options. Although gene therapy for HF is still being tested, patients who continue to be limited by severe HF symptoms despite aggressive medical management and who are not eligible for assist devices or cardiac transplantation may potentially benefit from these newer modalities of treatment. We have previously demonstrated that approximately $5 \%$ of patients undergoing coronary angiography for angina may not be candidates for traditional methods of revascularization and may be eligible for newer modalities of therapy [1]. Based on 1.4 million cardiac catheterizations performed in the US annually [2] around 70,000 patients per year may be eligible for newer methods of treatment. Moreover, the prognosis of these "no option" patients with refractory angina who are not amenable to traditional modes of revascularization remains poor with a mortality rate up to $17 \%$ at 1 year [3].

\section{Maximal pharmacological therapy}

The importance of optimum medical therapy in these patients with symptomatic CAD who are not candidates for revascularization cannot be overemphasized. Management includes discontinuation of tobacco use (all forms), lipid reduction with a target low-density lipoprotein $<100 \mathrm{mg} / \mathrm{dl}$, and control of hyperglycemia. All patients with symptomatic CAD should receive aspirin, beta-blockers, and angiotensinconverting enzyme inhibitors, nitrates and lipid-lowering agents. And, similarly patients with CHF (depending on the underlying etiology) should receive maximal medical therapy which includes the above-mentioned medications and in addition spironolactone, digoxin and diuretics. Adherence to salt restriction and modification of dietary habits also play a very important role. Angiotensin-converting enzyme 
Table 1. Inclusion and exclusion criteria for candidacy for therapeutic angiogenesis clinical trials

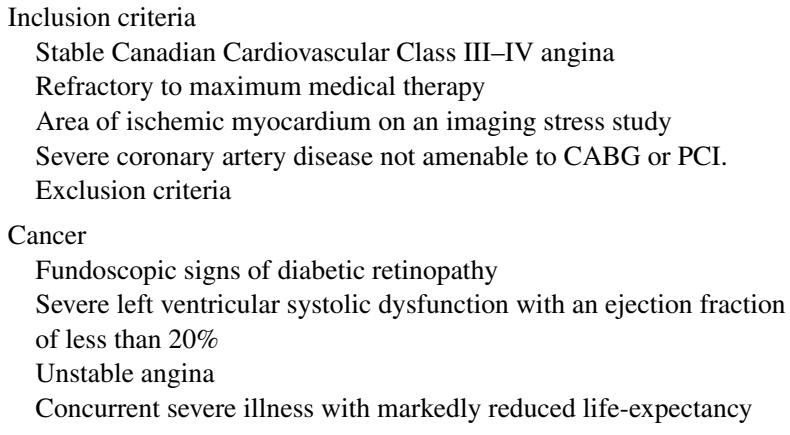

inhibitors not only have a salutary effect on left ventricular function but are also anti-ischemic, and may have angiogenic properties [4].

\section{Eligibility for newer modalities}

The inclusion and exclusion criteria for patients enrolled in contemporary clinical trials for therapeutic angiogenesis are listed in Table 1 [5]. For most of these trials, patients were considered eligible if they had stable Canadian Cardiovascular Class (CCC) III-IV angina refractory to maximum medical therapy, ischemic myocardium on an imaging stress study, and severe CAD that was not amenable to revascularization with CABG or PCI. Patients have been excluded in most clinical studies if they had evidence of cancer, fundoscopic signs of diabetic retinopathy and severe left ventricular systolic dysfunction with an ejection fraction of less than $20 \%$.

\section{Angiogenesis with growth factors}

"Therapeutic angiogenesis" with growth factors involves injection of growth factors capable of generating new blood vessels in an ischemic milieu. This was initially investigated successfully in patients with peripheral vascular occlusive disease. The native biologic response to vascular occlusion is development of collaterals and up-regulation of naturally occurring angiogens. Currently, therapeutic angiogenesis is being investigated in several arenas including myocardial ischemia, restenosis, HF and graft failure $[6,7]$ with a variety of delivery options (Fig. 1) [8].

A number of gene therapy vectors have been developed, including viral (retro- and adenoviruses) and non-viral vectors (plasmid DNA). Gene transfer with naked plasmid DNA is less efficient and viral vectors significantly increase gene transfer efficiency [9]. Retroviruses integrate with the host genome in a stable fashion, whereas adenoviruses lead to a transient transgene expression [7]. Most of the cardiovascular trials to date have used non-viral vectors [8]. Various method- ology for gene delivery have been tried including intravascular, intramyocardial via thoracotomy or percutaneous catheter technique and local delivery using microspheres coated with recombinant growth factors [9]. A promising new technique uses ultrasound with ultrasonic contrast agent and has been shown to improve gene transfer efficiency by 15-20-fold [1012]. This may allow intravenous injection of growth factors and obviate more invasive delivery methods in the future.

\section{Angiogenesis for myocardial ischemia}

\section{Vascular endothelial growth factor (VEGF)}

VEGF plays a pivotal role in the biology of angiogenesis and consists of several members including VEGFs A, B, C, D, E. The isoforms of VEGF-A have been used in most of the clinical trials (VEGF-121 and -165) [7]. Numerous studies have demonstrated that VEGF is up-regulated in the presence of myocardial ischemia and its expression is mediated through a factor called hypoxia inducible factor-1 (HIF-1). Both VEGF plamid cDNA and protein have been used in clinical trials.

Intramyocardial injection of plasmid DNA encoding 165amino acid isoform of VEGF (phVEGF) was studied in 30 patients in a Phase I clinical trial [13]. Out of the 30 patients, 29 of them experienced reduced angina, and use of sublingual nitroglycerin. Exercise tolerance improved after gene transfer with complete elimination of angina in $12 / 20$ patients at 6 months and in 7/10 patients followed over 12 months. Overall, at 1 year, CCC functional angina class had improved by at least 2 classes in $27 / 30$ patients and $14 / 30$ patients were free of angina with normal activities [13]. A following trial in 30 patients with chronic stable angina evaluated direct intramyocardial injection of cDNA encoding for VEGF-2 via minithoracotomy and these patients had similar clinical improvement at 1-year [14]. Overall, at 1 year in these two, Phase I clinical trials, there were two deaths, three acute myocardial infarctions, one transient ischemic attack, and three episodes of HF. None of these adverse events could be attributed to gene transfer. They were likely related to underlying extensive CAD and operative procedure in these high-risk population [9]. Isner et al., demonstrated similar clinical magnitude of clinical improvement at 1 year in 30 patients with class III or IV angina using transepicardial VEGF-2 gene transfer [8]. A total of 13 consecutive patients with chronic stable angina who failed conventional therapy were treated with intramyocardial injection of phVEGF-165 via mini-thoracotomy in a study by Vale et al. [15]. Objective evidence of improved myocardial perfusion was documented both by dipyridamole SPECT-sestamibi perfusion scans and left ventricular electromechanical mapping (EMM). These modalities were used to distinguish ischemic from infarcted myocardium and demonstrated significant improvement in myocardial ischemia after phVEGF gene transfer $(15.26 \pm 0.98 \%$ vs. 9.94 $\pm 1.53 \%, p$-value 0.004$)$. These results indicated that gene 


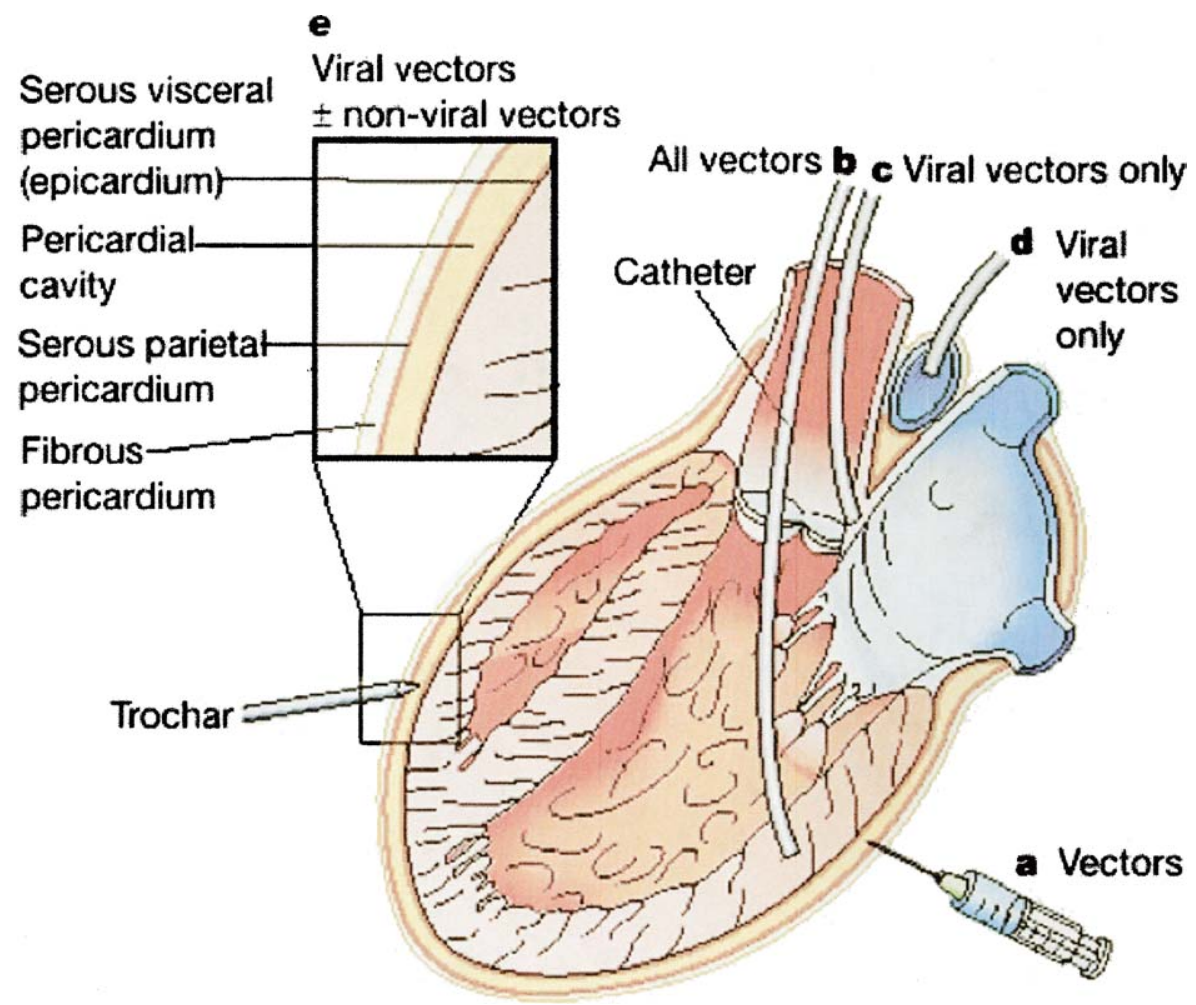

Fig. 1. Delivery options for myocardial gene transfer. (a) Epicardial. After intraoperative intramyocardial injection, the transgene is distributed to local cardiomyocytes and/or myocardial interstitium. (b) Endocardial. After catheter-based intramyocardial injection, the transgene is distributed in a similar way to that described in (a). (c) Intracoronary. Catheter injection directly into coronary arteries delivers the transgene by means of the coronary arterial circulation to a broad sample of cardiomyocytes and/or myocardial interstitium in the area subserved by the injected, source artery. (d) Retroperfusion. Cannulation of a coronary sinus (or subselective vein) with concurrent occlusion of outflow from the coronary sinus distributes the transgene retrograde from coronary venous circulation through the capillary bed to cardiomyocytes and interstitium in potentially all regions of left ventricular myocardium. (e) Intrapericardial. Transthoracic access to pericardium using a specialized catheter permits delivery into the pericardial space with secondary distribution directly to epicardial cardiomyocytes, and indirectly through the circulation shared by the peri- and epicardium. Reproduced from Isner [8].

transfer might successfully rescue hibernating myocardium [15]. In a study by Henry et al., 15 patients with ischemic myocardium who were not suitable for traditional revascularization received intracoronary VEGF during coronary angiography. There was improved myocardial perfusion, angiographic evidence of increased collateral density and symptomatic improvement [16]. Losordo et al., demonstrated that five patients who were given intramyocardial injection of VEGF DNA during minimally invasive surgery showed improvement in angina, nuclear perfusion scans, and angiography [17]. In another study using VEGF DNA, 16 patients with severe angina underwent direct intramyocardial injection of VEGF DNA. There was a significant decrease in anginal episodes, decreased use of nitroglycerin, and a significant improvement in perfusion [18]. A randomized trial of therapeutic angiogenesis with one intracoronary and three intravenous injections of VEGF, the vascular endothelial growth factor in ischemia for vascular angiogenesis (VIVA) demonstrated that VEGF offered no improvement beyond placebo in all measurements by day 60 [19]. By day 120, high-dose
VEGF resulted in significant improvement in angina and favorable trends in exercise time and angina frequency [19]. The negative results of this study can be possibly attributed to intravenous as opposed to intracoronary or intramyocardial administration of the growth factor and insufficient local delivery of VEGF after intravenous injections.

Several other clinical studies have evaluated viral vectors for gene transfer. Rosengart et al. performed a Phase I clinical trial using intramyocardial injection of adenovirus vector expressing human VEGF. Gene transfer in conjunction with CABG was compared to sole gene transfer via a minithoracotomy was studied in 21 patients. Both the groups had improvement in clinical angina and ischemic area. Myocardial administration of AdVEGF was well tolerated and had significant benefits at 30-day period [20]. At 6 months, similar results were demonstrated indicating the need for Phase II clinical trials [21]. The same investigators injected 10 patients with adenoviral VEGF transepicardially using video-assisted thoracotomy or thoracoscopy with symptomatic improvement and one late death. Table 2 summarizes the major studies 
Table 2. Clinical studies of therapeutic angiogenesis

\begin{tabular}{|c|c|c|c|c|c|c|}
\hline Author & Angiogen & Type of study & $N$ & Delivery method & End points & Comments \\
\hline Symes et al. [13] & VEGF $_{165}$ & $\begin{array}{l}\text { Observational/ } \\
\text { Phase I }\end{array}$ & 30 & IM & Ex. Tol angina & Improved \\
\hline Fortuin et al. [14] & VEGF-2 & Observational & 30 & IM via $\mathrm{MT}$ & Ex. Tol angina & Improved \\
\hline Isner et al. [8] & VEGF-2 & Observational & 30 & IM & Class III/IV angina & Improved \\
\hline Lathi et al. [72] & VEGF $_{165}$ & Observational & 30 & IM via $\mathrm{MT}$ & Class III/IV angina & Improved \\
\hline Vale et al. [15] & phVEGF $_{165}$ & Observational & 13 & IM via $\mathrm{MT}$ & Perfusion & Improved \\
\hline Henry et al. [16] & VEGF DNA & Observational & 15 & $\mathrm{IC}$ & Perfusion collaterals angina & Improved \\
\hline Losordo et al. [17] & VEGF DNA & Observational & 5 & IM & Angina perfusion angiogram & Improved \\
\hline Losordo et al. [18] & VEGF DNA & Observational & 16 & IM & Angina NTG use perfusion & Improved reduced NTG use \\
\hline Henry et al. [19] & VEGF protein & Randomized & 178 & IC vs. IV & Angina Perfusion & No improvement at 60 days \\
\hline Rosengart et al. [21] & $\begin{array}{l}\text { Adenovirus } \\
\text { VEGF }\end{array}$ & Randomized & 21 & $\begin{array}{l}\mathrm{IM}+\mathrm{CABG} \text { vs. IM } \\
\text { via } \mathrm{MT}\end{array}$ & Angina Ischemia & Improved \\
\hline Rosengart et al. [20] & $\begin{array}{l}\text { Adenovirus } \\
\text { VEGF }\end{array}$ & Observational & 10 & Trans-epicardial & Angina & Improved \\
\hline Grines et al. [30] & FGF-4 & DB/Randomized & 79 & IC vs. placebo & Ex. Tol & Improved \\
\hline Laham et al. [25] & FGF-2 & Observational & 24 & $\begin{array}{l}\text { Capsules implantation/ } \\
\text { CABG }\end{array}$ & Perfusion & Improved at high dose \\
\hline Sellke et al. [26] & FGF-2 & Observational & 8 & IM beads/CABG & Perfusion & $\begin{array}{l}\text { Three out of eight patients } \\
\text { improved }\end{array}$ \\
\hline Udelson et al. [27] & FGF-2 & Observational & 59 & $\mathrm{IC}$ & Perfusion & Improved \\
\hline Schumacher et al. [28] & FGF-1 & Randomized & 20 & IM/CABG vs. Placebo & Collaterals & Improved \\
\hline Simons et al. [29] & FGF-2 & Randomized & 337 & $\mathrm{IC}$ & Ex. Tol perfusion & $\begin{array}{l}\text { Improvement at } 90 \text { days but } \\
\text { not at } 180 \text { days }\end{array}$ \\
\hline
\end{tabular}

Ex. Tol: exercise tolerance; IM: intramuscular; IV: intravenous; IC: intracoronary; MT: mini-thoracotomy; CABG: coronary artery bypass graft; NTG: nitroglycerin; DB: double blind; $N=$ number of patients.

evaluating growth factors for therapeutic angiogenesis and Fig. 2 demonstrates new blood vessel formation after intramyocardial injection of phVEGF 165 .

\section{Fibroblast growth factor ( FGF)}

FGFs have also been studied in various trials with promising results. Acidic FGF (FGF-1) and basic FGF (FGF-2) affect various types of cells in addition to endothelial cells like fibroblasts and smooth muscle cells. FGFs (FGF-1-9) can also induce angiogenesis in vivo. FGF-1, FGF-2 and FGF-5 have been the agents used most commonly [22-24]. FGF-2 was implanted via heparin alginate capsules near occluded vessels at the time of CABG by Laham et al. [25] and improved perfusion was noted in patients receiving FGF2 in a dose-dependent manner. Eight patients undergoing CABG received intramyocardial injections of FGF-2 in slow release beads in an area of the myocardium not amenable to revascularization in another study [26]. Three patients demonstrated improved perfusion in the non-revascularized region on follow-up nuclear perfusion scans [26]. Intracoronary FGF-2 in patients who are not candidates for CABG has shown improvement in reversible ischemia on SPECT my- ocardial scan [27]. In a study by Schumacher et al. [28], 20 patients undergoing $\mathrm{CABG}$ received an intramyocardial injection of FGF-1 near the insertion of the internal mammary graft. Compared with 20 patients treated with placebo injections, the treated patients had evidence of increased collateral growth at follow-up angiography (Fig. 3) [28]. The randomized FGF Initiating RevaScularization Trial (FIRST) demonstrated that a single intracoronary FGF-2 infusion seems to resultin short-term symptomatic improvement that is most pronouncedin the more symptomatic patient subgroups; however, this didnot translate into improved exercise tolerance [29]. The multicenter, double-blind, placebo-controlled randomized angiogenic gene therapy (AGENT) trial of direct intracoronary administration of adenovirus encoding FGF4 demonstrated safety and showed a overall trend towards improvement in exercise tolerance [30]. Concordant with the FIRST trial, greatest improvement were noted in patients with baseline ETT $\leq 10 \mathrm{~min}$ or in the sicker patients [30].

Other growth factors

Hepatocyte growth factor also has angiogenic activity via induction of VEGF. Recombinant HGF was shown to 


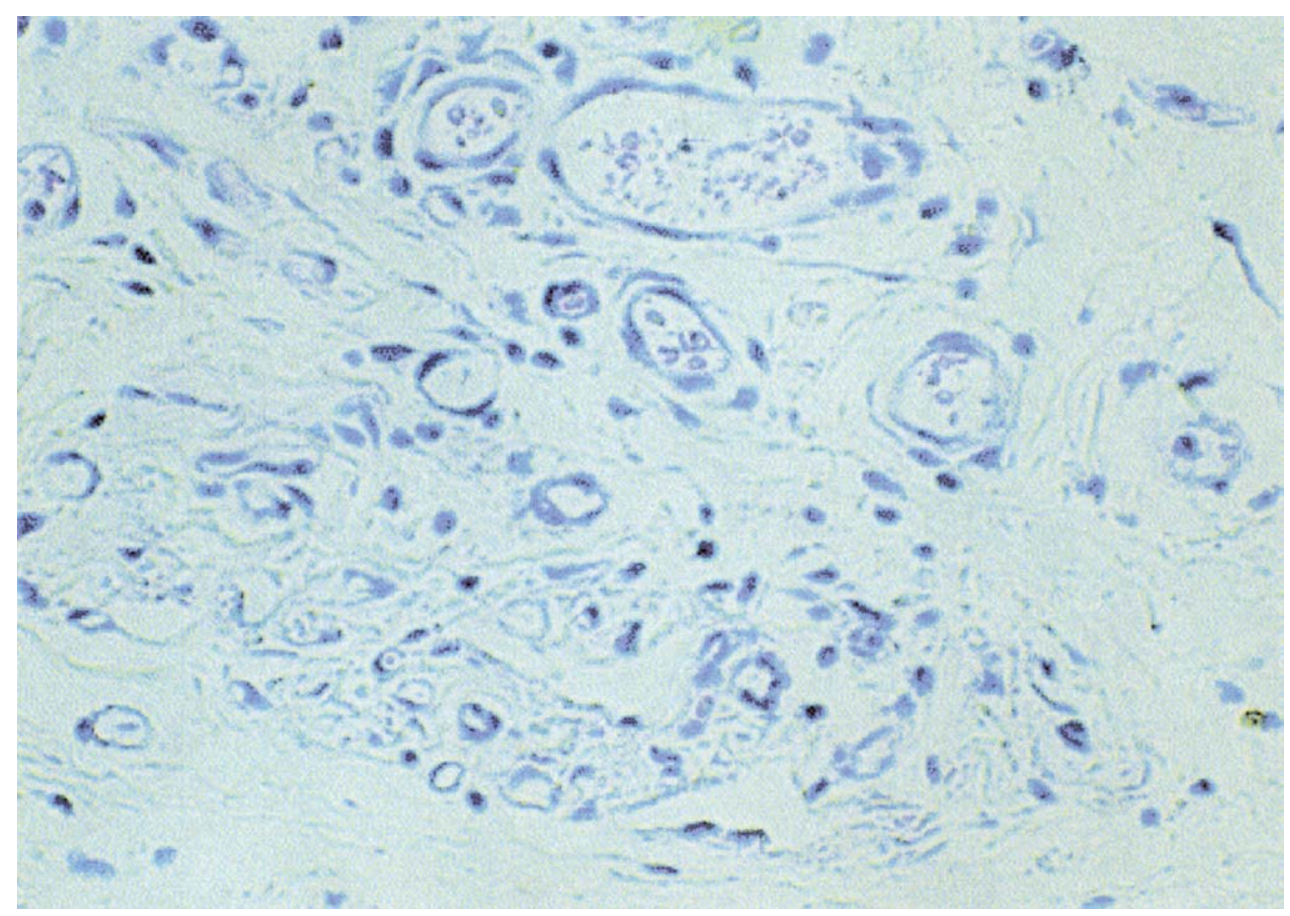

Fig. 2. Typical H + E example of phVEFF 165 -treated heart. New blood vessels are seen within angiomatous structure after intramyocardial injection of phVEGF $_{165}$. The cells are primarily composed of a few endothelial cells forming a ring. Reproduced from Schwarz et al. [71].

stimulate angiogenesis in rabbit ischemic limb model [31]. Angiopoietin-1 and angiopoietin-2 modify angiogenesis by causing maturation and stability in the new vessels after VEGF gene therapy [32]. An adenoviral vector was used to achieve gene transfer of active form of hypoxia inducible factor-1 alpha (HIF-1 alpha). HIF-1 alpha has been shown to augment collateral vessels in animal models [33] and clinical results are pending. Other factors like monocyte chemotactic protein-1 and platelet-derived growth factor [34] may mediate angiogenesis via VEGF.

In summary, the current weight of evidence favors direct intramyocardial delivery of growth factors, but intracoronary and intravenous delivery has not been consistently successfull. In the future, enhanced local delivery of these growth factors using ultrasound or other techniques may make peripheral intravenous injection feasible by significantly augmenting local delivery.

\section{Combination of bypass surgery and gene therapy}

Therapeutic angiogenesis may play an important role in patients who are not candidates for any revascularization and also in the group of patients who require $\mathrm{CABG}$, but complete revascularization may not be feasible in some arterial distributions. These patients might benefit from a combined approach of CABG and angiogenesis. Feasibility of this combined approach has been shown in small preliminary trials $[21,25,28]$. Such an approach may open more avenues such as decreased utilization of saphenous vein grafts with limited patency if indeed gene therapy appears to benefit ungraftable territories.

\section{Risks/concerns with growth-factor-mediated myocardial angiogenesis}

The main concern about growth-factor-mediated angiogenesis is pathological angiogenesis. This is thought to play a role in several diseases including tumor growth, diabetic proliferative retinopathy, and progression of atherosclerosis [35]. Growth factors may contribute to the growth of malignant tumors, and because of this patients with a history of cancer has been excluded from the trials. There has been no report of increased new malignancy in the clinical trials to date. Another concern is development/woresing of diabetic retinopathy. At present there are no reports of neovascularization in the retina, despite formal ophthalmological exams in most of the clinical trials. Initially diabetics were excluded, but several trials now include diabetics without retinopathy. In the clinical trials so far there has been no increase in acute ischemic syndromes or progression of atherosclerosis observed on serial angiography. Despite initial concerns, treatment with both VEGF and FGF has been well tolerated in the clinical trials. Both drugs may cause transient hypotension at high doses or with rapid infusion. Slowing the infusion rate may help in these patients. There have been rare reports of proteinuria and thrombocytopenia with FGF, and spider angiomas and peripheral edema with VEGF. 

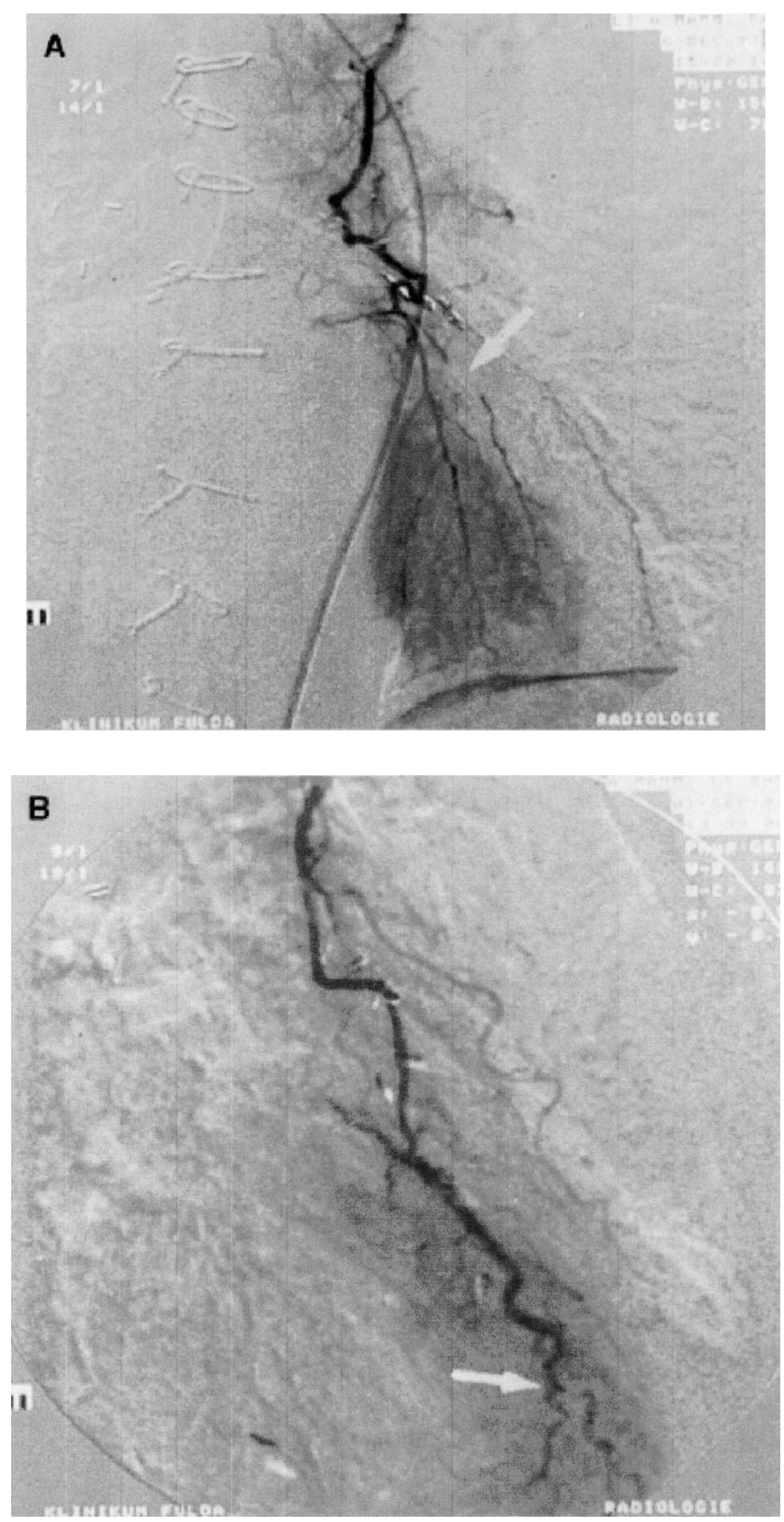

Fig. 3. (A) Collateralization of stenoses (arrow): a diagonal branch occluded just distal to its origin is filled through the newly grown capillaries. At the site of injection of the FGF-I, a capillary network couldbe seen sprouting out from the coronary artery into the myocardium. (B) The peripherally stenosed LAD is filled through newly grown capillaries. Such "neocapillary vessels" can alsoprovide a collateral circulation around additional distal stenosesof the LAD and bring about retrograde filling of ashort segment of the artery distal to the stenosis. Reproduced from Schumacher et al. [28]. 


\section{Coronary artery restenosis and angiogenesis}

The incidence of post-PCI restenosis remains approximately $15-20 \%$ in native coronary arteries and significantly higher in vein grafts [7]. Current solutions that are being investigated include gene therapy for amelioration of restenosis. Antisense constructs against c-myc, ras, bcl-x, etc. have decreased intimal thickening in experimental models [36, 37]. Smooth muscle cell proliferation can be reduced by blocking PDGF [38]. To be successful, all the above molecules have to be efficiently transfected into host genome. One efficient method could be autologous in vitro transfection outside the body and implantation at the needed site. VEGF stimulates nitric oxide [39] and releases prostaglandin-I which prevent smooth muscle cell proliferation. Local delivery of VEGF to prevent re-stenosis may also be potentially useful. The current availability of drug-coated stents with $<5 \%$ restenosis $[40,41]$ may however limit the usefulness and affect development of these investigative modalities.

\section{Role of myocardial angiogenesis in heart failure}

A strategy of "molecular ventricular assistance" has been proposed for treatment of refractory HF [42]. Prior studies have revealed that reduced expression of sarcoplasmic reticulum $\mathrm{Ca}^{2+}$-ATPase (SERCA) plays a role in congestive HF [43]. Miyamoto et al. [44] showed that adenoviral overexpression of SERCA 2A restored systolic and diastolic function in a rat model and left ventricular size was reduced. SERCA $2 \mathrm{a}$ expression decreased $\mathrm{Ca}^{2+}$ prevents activation of calcineurin, thus preventing myocyte hypertrophy. Overexpression of SERCA rescues calcium cycling in the failing heart [45].
Beta adrenergic receptors (beta-ARs) play a major role in HF. Down-regulated beta-ARs, can be remedied with intracoronary injection of viral particles encoding beta-AR in rabbits with persistent expression for up to 3 weeks [46]. To circumvent beta receptors, adenoviral gene transfer of vasopressin V2 receptors which increase dp/dt has been performed in rats [47]. Intracoronary injection of adenoviral beta-ARK1 inhibitor lead to improved systolic function in rabbit models with increased $\mathrm{dP} / \mathrm{dt}$. A potential problem with this is sustained adrenergic stimulation and arrhythmias. Apoptosis, programmed cell death, seems to play an important role in $\mathrm{HF}$ and in vitro studies in animal models using adenoviral Bcl-2 to block apoptosis mediated by p53 have been performed.

\section{Cell transplantation}

The potential of cell therapy in cardiovascular diseases is rapidly evolving. Two types of cells may be used for this therapy. These are differentiated cells and stem cells. This exciting new approach for the treatment of HF and myocardial ischemia [48] can also be used as compliment to gene therapy. Fetal cardiomyocytes [49], autologous skeletal myoblasts [50-52] and mesenchymal stem cells have shown to improve myocardial function in pre-clinical trials. Initial studies evaluated autologous cell transplantation using cardiac myocytes or skeletal muscle cells into normal hearts [53, 54]. The important observation from these experiments was that ventricular arrhythmias were not induced by cell engraftment.

Subsequently, studies were done looking at injured myocardium in animal models [55-59]. Myocardial injury was induced by ligating artery or by cryoinjury to theepicardium.

Table 3. Pre-clinical and clinical studies of cell transplantation (adapted from [70])

\begin{tabular}{|c|c|c|c|c|c|}
\hline Author & Animal model & Transplantation type & Cell type & Time after infarct & $\mathrm{LV}^{*}$ function \\
\hline Marelli et al. [57] & Dog & Differentiated & Skeletal myoblasts & Immediate & N/A \\
\hline Murry et al. [51] & Rat & Differentiated & Skeletal myoblasts & Immediate & N/A \\
\hline Taylor et al. [59] & Rabbit & Differentiated & Skeletal myoblasts & Immediate & Improved \\
\hline Li et al. [55] & Rat & Differentiated & Smooth muscle cell & 4 weeks & Improved \\
\hline Li et al. [56] & Porcine & Differentiated & Heart cells & 4 weeks & N/A \\
\hline Rajnoch et al. [58] & Sheep & Differentiated & Skeletal myoblasts & 3 weeks & Improved \\
\hline Tomita et al. [61] & Rat & Stem cell-direct & Bone marrow & 3 weeks & Improved \\
\hline Kocher et al. [60] & Rat & Stem cell-direct & Bone marrow & $48 \mathrm{~h}$ & Improved \\
\hline Beltrami et al. [63] & Human & Stem cell mobilization & Cardiac myoblasts & 4-12 days & Increased muscle mass \\
\hline Jackson et al. [62] & Mouse & Stem cell mobilization & Myocytes, endothelial cells & 4 weeks & Endothelial engraftment \\
\hline Askari et al. [66] & Rat & $\begin{array}{l}\text { Stem cell mobilization }+ \\
\text { direct transplantation }\end{array}$ & Skeletal myoblasts & 4 weeks & $\begin{array}{c}\text { Increase in left ventricular mass } \\
\text { and better cardiac function }\end{array}$ \\
\hline
\end{tabular}

${ }^{*} \mathrm{LV}$ : left ventricular function; N/A: not available. 
Transplantation of differentiated cells was demonstrated to be successful in several animal models (Table 3). In these studies, fetal myoblasts did not offer improved efficacy when compared to other cells. The mechanism by how these cells help is not yet well understood. Whether it improves contractility of infarcted area or helps with post-infarct remodeling [51] is yet to be delineated but more likely it affects remodeling. If cell transplantation indeed improves contractility, then time to transplantation should not play a major role in efficacy. But, if post-infarct remodeling is the major mechanism, then time to cell transplantation becomes critical. Regeneration of infarcted myocardium using stem cells can be done either by direct injection into myocardium $[60,61]$ or by mobilizing specific cell population $[62,63]$ by various stimulating mediators like VEGF [64]. The combination of replacing senescent cells by cell transplantation and deliver gene products via gene therapy (VEGF) has led to enhanced capillary density and blood flow in rat hearts [65]. Askari et al., studied the effects of stem-cell mobilization by use of granulocyte colony-stimulating factor with or without transplantation of syngeneic skeletal myoblasts cells and demonstrated that a combined strategy of gene transfer and stem-cell mobilization, results in regeneration of myocardium in a model of ischemic cardiomyopathy [66].

Severe Angina (Class III-IV)

Positive Stress test

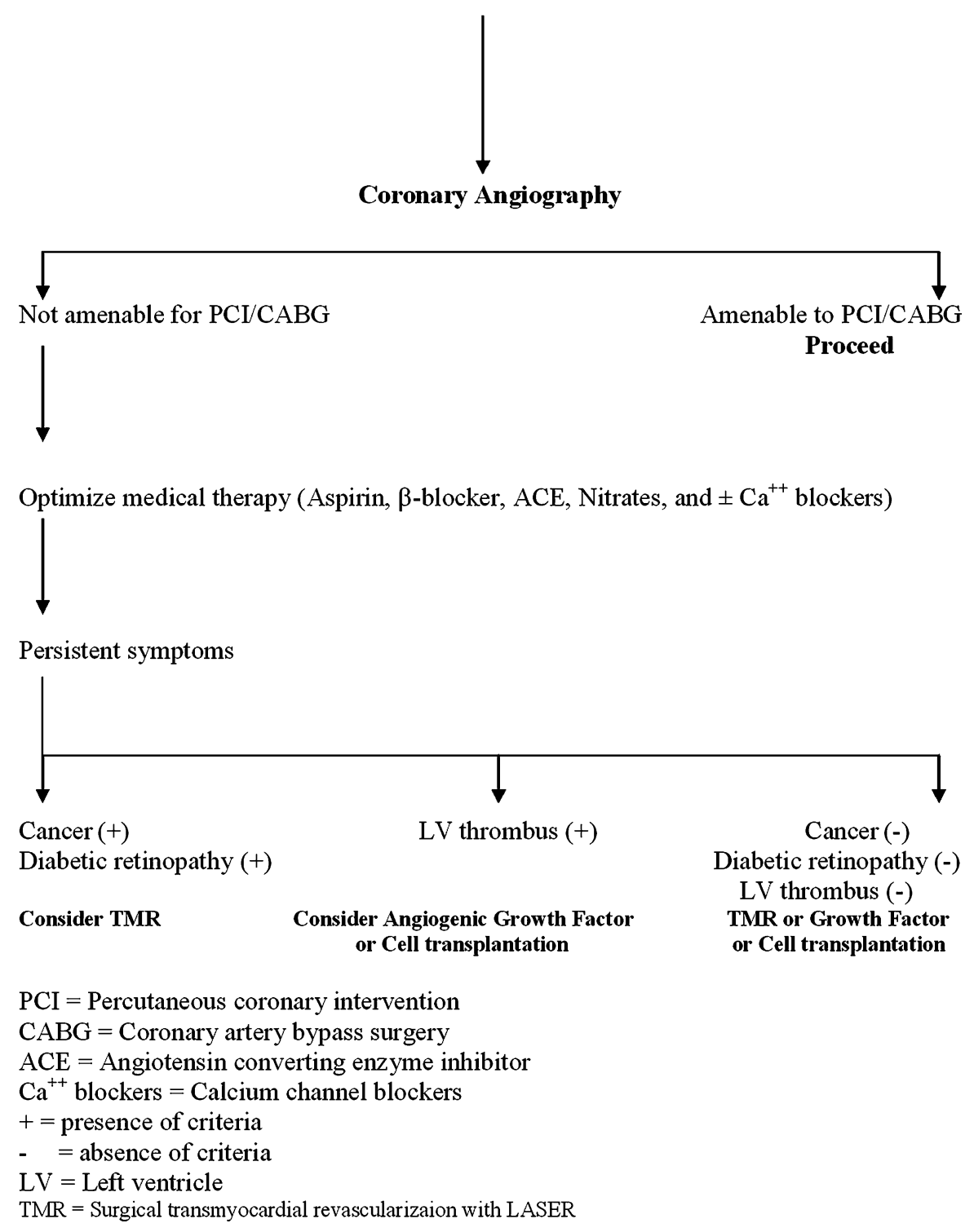

Fig. 4. Treatment algorithm for patients with refractory myocardial ischemia. 
This combined modality has a potential to offer a new treatment modality for ischemia and HF. Several studies of stem cell transplantation are summarized in Table 3.

After initial success in animal studies, clinical trials have been initiated. Hamano et al., reported their experience with mononuclear rich autologous cell injection into myocardium along with CABG [67] and demonstrated improved local wall thickening dynamics, presumably due to the angiogenesis induced by the treatment. In patients afflicted with end stage $\mathrm{HF}$, pleuripotent adult stem cell transplantation has lead to some evidence of myocardial regeneration [60-62]. HMG $\mathrm{CoA}$ reductase inhibitors which have been shown to be significantly beneficial in patients with CAD have been shown to increase the circulating levels of endothelial progenitor cells [68]. There seems to be significant potential for autologous cell transplantation to heal injured myocardium $[69,70]$ but needs to be validated in prospective trials.

\section{Conclusions}

A significant proportion of patients with symptomatic CAD and end stage HF may not be candidates for conventional therapeutic options like PCI or CABG and heart transplantation. Therapeutic angiogenesis with growth factors, cell transplantation with myoblasts and genetically engineered cells may improve morbidity in these cohort of patients. Current trials have only enrolled patients with severe symptomatic CAD or peripheral vascular disease. In the future, it may also benefit patients with ischemic cardiomyopathy, end-stage HF, post cardiac transplant atherosclerosis, severe restenosis, inherited lipid disorders and patients with microvascular disease. Cell transplantation with differentiated and stem cells have shown significant potential in animal studies and preliminary reports of small case series but needs to be prospectively validated in larger appropriately designed studies. The future may hold many more therapeutic options for patients with advanced ischemic heart disease. Figure 4 is a simplified algorithm for the approach and management of patients with refractory myocardial ischemia not amenable to traditional methods of revascularization.

\section{References}

1. Mukherjee D, Bhatt DL, Roe MT, Patel V, Ellis SG: Direct myocardial revascularization and angiogenesis - How many patients might be eligible? Am J Cardiol 84: 598-600, 1999

2. American Heart Association: 2002 Heart and Stroke Statistical Update, 2002

3. Mukherjee D, Comella K, Bhatt DL, Roe MT, Patel V, Ellis SG: Clinical outcome of a cohort of patients eligible for therapeutic angiogenesis or transmyocardial revascularization. Am Heart J 142: 72-74, 2001

4. Silvestre JS, Kamsu-Kom N, Clergue M, Duriez M, Levy BI: Verylow-dose combination of the angiotensin-converting enzyme inhibitor perindopril and the diuretic indapamide induces an early and sustained increase in neovascularization in rat ischemic legs. J Pharmacol Exp Ther 303: 1038-1043, 2002

5. Mukherjee D, Ellis SG: New options for untreatable coronary artery disease: Angiogenesis and laser revascularization. Cleve Clin J Med 67: 577-583, 2000

6. Tamirisa KP, Mukherjee D: Gene therapy in cardiovascular diseases. Curr Gene Ther 2: 427-435, 2002

7. Yla-Herttuala S, Martin JF: Cardiovascular gene therapy. Lancet 355 : 213-222, 2000

8. Isner JM: Myocardial gene therapy. Nature 415: 234-239, 2002

9. Symes J: Gene therapy for ischemic heart disease: Therapeutic potential. Am J Cardiovasc Drugs 1: 159-166, 2001

10. Schratzberger P, Tkebuchava T, Kirchmair R, Milliken C, Bahlmann F, Tepper, Kawamoto A, Iwaguro H, Pola R, Zuk R, Brisken A, Vale P, Isner J: Ultrasound enhances therapeutic gene expression in ischemic pig myocardium. J Am Coll Cardiol 37: 266A, 2001

11. Mukherjee D, Wong J, Griffin B, Ellis SG, Porter T, Sen S, Thomas JD: Ten-fold augmentation of endothelial uptake of vascular endothelial growth factor with ultrasound after systemic administration. J Am Coll Cardiol 35: 1678-1686, 2000

12. Zhou Z, Mukherjee D, Wang K, Zhou X, Tarakji K, Ellis K, Chan A, Penn M, Ostensen J, Thomas J, Garcia M, Topol E, Ellis S: Induction of angiogenesis in a Canine model of chronic myocardial ischemia with intravenous infusion of vascular endothelial growth factor (VEGF) combined with ultrasound energy and echo contrast agent. J Am Coll Cardiol 39: 396A, 2002

13. Symes JF, Losordo DW, Vale PR, Lathi KG, Esakof DD, Mayskiy M, Isner JM: Gene therapy with vascular endothelial growth factor for inoperable coronary artery disease. Ann Thorac Surg 68: 830-836, 1999

14. Fortuin F, Vale P, Losordo D, DeLaria G, Tyner J, Symes J, Schaer G, Lopez J, Van Camp J, Henry T, Richenbacher W, Rogers J, Isner J, Schatz R: Direct myocardial gene transfer of vascular endothelial growth factor-2 (VEGF-2) naked DNA via thoracotomy relieves angina pectoris and increases exercise time: One-year follow-up of a completed dose. J Am Coll Cardiol 37: 285A, 2001

15. Vale PR, Losordo DW, Milliken CE, Maysky M, Esakof DD, Symes JF, Isner JM: Left ventricular electromechanical mapping to assess efficacy of phVEGF (165) gene transfer for therapeutic angiogenesis in chronic myocardial ischemia. Circulation 102: 965-974, 2000

16. Henry T, Rocha-Singh K, Isner J, Keriakes D, Giordano F, Simons M: Results of intracoronary recombinant human vascular endothelial growth factor (rhVEGF) administration trial. J Am Coll Cardiol 31: 65A, 1998

17. Losordo DW, Vale PR, Symes JF, Dunnington CH, Esakof DD, Maysky M, Ashare AB, Lathi K, Isner JM: Gene therapy for myocardial angiogenesis: Initial clinical results with direct myocardial injection of phVEGF165 as sole therapy for myocardial ischemia. Circulation 98: 2800-2804, 1998

18. Losordo DW, Vale PR, Isner JM: Gene therapy for myocardial angiogenesis. Am Heart J 138: S132-S141, 1999

19. Henry TD, Annex BH, McKendall GR, Azrin MA, Lopez JJ, Giordano FJ, Shah PK, Willerson JT, Benza RL, Berman DS, Gibson CM, Bajamonde A, Rundle AC, Fine J, McCluskey ER: The VIVA trial: Vascular endothelial growth factor in ischemia for vascular angiogenesis. Circulation 107: 1359-1365, 2003

20. Rosengart TK, Lee LY, Patel SR, Sanborn TA, Parikh M, Bergman GW, Hachamovitch R, Szulc M, Kligfield PD, Okin PM, Hahn RT, Devereux RB, Post MR, Hackett NR, Foster T, Grasso TM, Lesser ML, Isom OW, Crystal RG: Angiogenesis gene therapy: Phase I assessment of direct intramyocardial administration of an adenovirus vector expressing VEGF121 cDNA to individuals with clinically significant severe coronary artery disease. Circulation 100: 468-474 1999 
21. Rosengart TK, Lee LY, Patel SR, Kligfield PD, Okin PM, Hackett NR, Isom OW, Crystal RG: Six-month assessment of a phase I trial of angiogenic gene therapy for the treatment of coronary artery disease using direct intramyocardial administration of an adenovirus vector expressing the VEGF121 cDNA. Ann Surg 230: 466-470; discussion 470-462, 1999

22. Pu LQ, Sniderman AD, Brassard R, Lachapelle KJ, Graham AM, Lisbona R, Symes JF: Enhanced revascularization of the ischemic limb by angiogenic therapy. Circulation 88: 208-215, 1993

23. Giordano FJ, Ping P, McKirnan MD, Nozaki S, DeMaria AN, Dillmann WH, Mathieu-Costello O, Hammond HK: Intracoronary gene transfer of fibroblast growth factor-5 increases blood flow and contractile function in an ischemic region of the heart. Nat Med 2: 534-539, 1996

24. Safi J, Jr., Gloe TR, Riccioni T, Kovesdi I, Capogrossi MC: Gene therapy with angiogenic factors: A new potential approach to the treatment of ischemic diseases. J Mol Cell Cardiol 29: 2311-2325, 1997

25. Laham RJ, Sellke FW, Edelman ER, Pearlman JD, Ware JA, Brown DL, Gold JP, Simons M: Local perivascular delivery of basic fibroblast growth factor in patients undergoing coronary bypass surgery: Results of a phase I randomized, double-blind, placebo-controlled trial. Circulation 100: 1865-1871, 1999

26. Sellke FW, Laham RJ, Edelman ER, Pearlman JD, Simons M: Therapeutic angiogenesis with basic fibroblast growth factor: Technique and early results. Ann Thorac Surg 65: 1540-1544, 1998

27. Udelson JE, Dilsizian V, Laham RJ, Chronos N, Vansant J, Blais M, Galt JR, Pike M, Yoshizawa C, Simons M: Therapeutic angiogenesis with recombinant fibroblast growth factor-2 improves stress and rest myocardial perfusion abnormalities in patients with severe symptomatic chronic coronary artery disease. Circulation 102: 1605-1610, 2000

28. Schumacher B, Pecher P, von Specht BU, Stegmann T: Induction of neoangiogenesis in ischemic myocardium by human growth factors: First clinical results of a new treatment of coronary heart disease. Circulation 97: 645-650, 1998

29. Simons M, Annex BH, Laham RJ, Kleiman N, Henry T, Dauerman H, Udelson JE, Gervino EV, Pike M, Whitehouse MJ, Moon T, Chronos NA: Pharmacological treatment of coronary artery disease with recombinant fibroblast growth factor-2: Double-blind, randomized, controlled clinical trial. Circulation 105: 788-793, 2002

30. Grines CL, Watkins MW, Helmer G, Penny W, Brinker J, Marmur JD, West A, Rade JJ, Marrott P, Hammond HK, Engler RL: Angiogenic Gene Therapy (AGENT) trial in patients with stable angina pectoris. Circulation 105: 1291-1297, 2002

31. Vanbelle E., Maillard L., Tio FO, Isner JM: Scatter factor stimulates angiogenesis in a rabbit model of hindlimb ischemia. Circulation. 92: 78,1995

32. Shyu KG, Manor O, Magner M, Yancopoulos GD, Isner JM: Direct intramuscular injection of plasmid DNA encoding angiopoietin-1 but not angiopoietin-2 augments revascularization in the rabbit ischemic hindlimb. Circulation 98: 2081-2087, 1998

33. Vincent KA, Shyu KG, Luo Y, Magner M, Tio RA, Jiang C, Goldberg MA, Akita GY, Gregory RJ, Isner JM: Angiogenesis is induced in a rabbit model of hindlimb ischemia by naked DNA encoding an HIF-1alpha/VP16 hybrid transcription factor. Circulation 102: 2255-2261, 2000

34. Martins RN, Chleboun JO, Sellers P, Sleigh M, Muir J: The role of PDGF-BB on the development of the collateral circulation after acute arterial occlusion. Growth Factors 10: 299-306, 1994

35. Inoue $M$, Itoh $H$, Ueda M, Naruko T, Kojima A, Komatsu R, Doi K, Ogawa Y, Tamura N, Takaya K, Igaki T, Yamashita J, Chun TH, Masatsugu K, Becker AE, Nakao K: Vascular endothelial growth factor (VEGF) expression in human coronary atherosclerotic lesions: Possible pathophysiological significance of VEGF in progression of atherosclerosis. Circulation 98: 2108-2116, 1998
36. Pollman MJ, Hall JL, Mann MJ, Zhang L, Gibbons GH: Inhibition of neointimal cell bcl-x expression induces apoptosis and regression of vascular disease. Nat Med 4: 222-227, 1998

37. Indolfi C, Avvedimento EV, Rapacciuolo A, Di Lorenzo E, Esposito G, Stabile E, Feliciello A, Mele E, Giuliano P, Condorelli G, et al.: Inhibition of cellular ras prevents smooth muscle cell proliferation after vascular injury in vivo. Nat Med 1: 541-545, 1995

38. Hart CE, Kraiss LW, Vergel S, Gilbertson D, Kenagy R, Kirkman T, Crandall DL, Tickle S, Finney H, Yarranton G, Clowes AW: PDGFbeta receptor blockade inhibits intimal hyperplasia in the baboon. Circulation 99: 564-569, 1999

39. van der Zee R, Murohara T, Luo Z, Zollmann F, Passeri J, Lekutat C, Isner JM: Vascular endothelial growth factor/vascular permeability factor augments nitric oxide release from quiescent rabbit and human vascular endothelium. Circulation 95: 1030-1037, 1997

40. Morice MC, Serruys PW, Sousa JE, Fajadet J, Ban Hayashi E, Perin M, Colombo A, Schuler G, Barragan P, Guagliumi G, Molnar F, Falotico R: A randomized comparison of a sirolimus-eluting stent with a standard stent for coronary revascularization. N Engl J Med 346: 1773-1780, 2002

41. Colombo A, Drzewiecki J, Banning A, Grube E, Hauptmann K, Silber S, Dudek D, Fort S, Schiele F, Zmudka K, Guagliumi G, Russell ME: Randomized study to assess the effectiveness of slow- and moderate-release polymer-based paclitaxel-eluting stents for coronary artery lesions. Circulation 108: 788-794, 2003

42. Shah AS, White DC, Emani S, Kypson AP, Lilly RE, Wilson K, Glower DD, Lefkowitz RJ, Koch WJ: In vivo ventricular gene delivery of a beta-adrenergic receptor kinase inhibitor to the failing heart reverses cardiac dysfunction. Circulation 103: 1311-1316, 2001

43. Schmidt U, Hajjar RJ, Helm PA, Kim CS, Doye AA, Gwathmey JK: Contribution of abnormal sarcoplasmic reticulum ATPase activity to systolic and diastolic dysfunction in human heart failure. J Mol Cell Cardiol 30: 1929-1937, 1998

44. Miyamoto MI, del Monte F, Schmidt U, DiSalvo TS, Kang ZB, Matsui T, Guerrero JL, Gwathmey JK, Rosenzweig A, Hajjar RJ: Adenoviral gene transfer of SERCA2a improves left-ventricular function in aortic-banded rats in transition to heart failure. Proc Natl Acad Sci USA 97: 793-798, 2000

45. He H, Giordano FJ, Hilal-Dandan R, Choi DJ, Rockman HA, McDonough PM, Bluhm WF, Meyer M, Sayen MR, Swanson E, Dillmann WH: Overexpression of the rat sarcoplasmic reticulum $\mathrm{Ca}^{2+}$ ATPase gene in the heart of transgenic mice accelerates calcium transients and cardiac relaxation. J Clin Invest 100: 380-389, 1997

46. Maurice JP, Hata JA, Shah AS, White DC, McDonald PH, Dolber PC, Wilson KH, Lefkowitz RJ, Glower DD, Koch WJ: Enhancement of cardiac function after adenoviral-mediated in vivo intracoronary beta2-adrenergic receptor gene delivery. J Clin Invest 104: 21-29, 1999

47. Weig HJ, Laugwitz KL, Moretti A, Kronsbein K, Stadele C, Bruning S, Seyfarth M, Brill T, Schomig A, Ungerer M: Enhanced cardiac contractility after gene transfer of $\mathrm{V} 2$ vasopressin receptors in vivo by ultrasound-guided injection or transcoronary delivery. Circulation 101: $1578-1585,2000$

48. Reinlib L, Field L: Cell transplantation as future therapy for cardiovascular disease? A Workshop of the National Heart, Lung, and Blood Institute. Circulation 101: E182-E187, 2000

49. Sakai T, Li RK, Weisel RD, Mickle DA, Jia ZQ, Tomita S, Kim EJ, Yau TM: Fetal cell transplantation: A comparison of three cell types. J Thorac Cardiovasc Surg 118: 715-724, 1999

50. Menasche P, Hagege AA, Scorsin M, Pouzet B, Desnos M, Duboc D, Schwartz K, Vilquin JT, Marolleau JP: Myoblast transplantation for heart failure. Lancet 357: 279-280, 2001 
51. Murry CE, Wiseman RW, Schwartz SM, Hauschka SD: Skeletal myoblast transplantation for repair of myocardial necrosis. J Clin Invest 98: 2512-2523, 1996

52. Scorsin M, Hagege A, Vilquin JT, Fiszman M, Marotte F, Samuel JL, Rappaport L, Schwartz K, Menasche P: Comparison of the effects of fetal cardiomyocyte and skeletal myoblast transplantation on postinfarction left ventricular function. J Thorac Cardiovasc Surg 119: 1169-1175, 2000

53. Koh GY, Klug MG, Soonpaa MH, Field LJ: Differentiation and long-term survival of $\mathrm{C} 2 \mathrm{C} 12$ myoblast grafts in heart. J Clin Invest 92: 1548-1554, 1993

54. Koh GY, Kim SJ, Klug MG, Park K, Soonpaa MH, Field LJ: Targeted expression of transforming growth factor-beta 1 in intracardiac grafts promotes vascular endothelial cell DNA synthesis. J Clin Invest 95: 114-121, 1995

55. Li RK, Jia ZQ, Weisel RD, Merante F, Mickle DA: Smooth muscle cell transplantation into myocardial scar tissue improves heart function. J Mol Cell Cardiol 31: 513-522, 1999

56. Li RK, Weisel RD, Mickle DA, Jia ZQ, Kim EJ, Sakai T, Tomita S, Schwartz L, Iwanochko M, Husain M, Cusimano RJ, Burns RJ, Yau TM: Autologous porcine heart cell transplantation improved heart function after a myocardial infarction. J Thorac Cardiovasc Surg 119: 62-68, 2000

57. Marelli D, Desrosiers C, el-Alfy M, Kao RL, Chiu RC: Cell transplantation for myocardial repair: An experimental approach. Cell Transplant 1: 383-390, 1992

58. Rajnoch C, Chachques JC, Berrebi A, Bruneval P, Benoit MO, Carpentier A: Cellular therapy reverses myocardial dysfunction. J Thorac Cardiovasc Surg 121: 871-878, 2001

59. Taylor DA, Atkins BZ, Hungspreugs P, Jones TR, Reedy MC, Hutcheson KA, Glower DD, Kraus WE: Regenerating functional myocardium: improved performance after skeletal myoblast transplantation. Nat Med 4: 929-933, 1998

60. Kocher AA, Schuster MD, Szabolcs MJ, Takuma S, Burkhoff D, Wang J, Homma S, Edwards NM, Itescu S: Neovascularization of ischemic myocardium by human bone-marrow-derived angioblasts prevents cardiomyocyte apoptosis, reduces remodeling and improves cardiac function. Nat Med 7: 430-436, 2001

61. Tomita S, Li RK, Weisel RD, Mickle DA, Kim EJ, Sakai T, Jia ZQ Autologous transplantation of bone marrow cells improves damaged heart function. Circulation 100: II247-II256, 1999
62. Jackson KA, Majka SM, Wang H, Pocius J, Hartley CJ, Majesky MW, Entman ML, Michael LH, Hirschi KK, Goodell MA: Regeneration of ischemic cardiac muscle and vascular endothelium by adult stem cells. J Clin Invest 107: 1395-1402, 2001

63. Beltrami AP, Urbanek K, Kajstura J, Yan SM, Finato N, Bussani R, Nadal-Ginard B, Silvestri F, Leri A, Beltrami CA, Anversa P: Evidence that human cardiac myocytes divide after myocardial infarction. $\mathrm{N}$ Engl J Med 344: 1750-1757, 2001

64. Shintani S, Murohara T, Ikeda H, Ueno T, Honma T, Katoh A, Sasaki K, Shimada T, Oike Y, Imaizumi T: Mobilization of endothelial progenitor cells in patients with acute myocardial infarction. Circulation 103: 2776-2779, 2001

65. Yau T, Zung K: Enhanced myocardial angiogenesis by gene transfer using transplanted cells. Circulation 102: II-682, 2000

66. Askari AT, Unzek S, Popovic ZB, Goldman CK, Forudi F, Kiedrowski M, Rovner A, Ellis SG, Thomas JD, DiCorleto PE, Topol EJ, Penn MS: Effect of stromal-cell-derived factor 1 on stem-cell homing and tissue regeneration in ischaemic cardiomyopathy. Lancet 362: 697-703, 2003

67. Hamano K, Li TS, Kobayashi T, Hirata K, Yano M, Kohno M, Matsuzaki M: Therapeutic angiogenesis induced by local autologous bone marrow cell implantation. Ann Thorac Surg 73: 1210-1215, 2002

68. Dimmeler S, Aicher A, Vasa M, Mildner-Rihm C, Adler K, Tiemann M, Rutten H, Fichtlscherer S, Martin H, Zeiher AM: HMG-CoA reductase inhibitors (statins) increase endothelial progenitor cells via the PI 3-kinase/Akt pathway. J Clin Invest 108: 391-397, 2001

69. Chande M: Stem cells get to the heart of the matter. Lancet 357: 1099, 2001

70. Penn MS, Francis GS, Ellis SG, Young JB, McCarthy PM, Topol EJ: Autologous cell transplantation for the treatment of damaged myocardium. Prog Cardiovasc Dis 45: 21-32, 2002

71. Schwarz ER, Speakman MT, Patterson M, Hale SS, Isner JM, Kedes LH, Kloner RA: Evaluation of the effects of intramyocardial injection of DNA expressing vascular endothelial growth factor (VEGF) in a myocardial infarction model in the rat-Angiogenesis and angioma formation. J Am Coll Cardiol 35: 1323-1330, 2000

72. Lathi KG, Vale PR, Losordo DW, Cespedes RM, Symes JF, Esakof DD, Maysky M, Isner JM: Gene therapy with vascular endothelial growth factor for inoperable coronary artery disease: Anesthetic management and results. Anesth Analg 92: 19-25, 2001 